\title{
Comparison of the Application of Media Using Software Anates Based On Evaluation College Learning at Batanghari University Jambi
}

\author{
Pratiwi Indah Sari ${ }^{1}$, Redi Indra Yudha ${ }^{2}$ \\ \{pradasari676@gmail.com ${ }^{1}$, ilcapitanoredi@gmail.com ${ }^{2}$ \} \\ ${ }^{1,2}$ Economic Education Program Study, FKIP UNBARI, Jambi
}

\begin{abstract}
This study aims to determine how student learning outcomes using Anates software based media with those not using learning evaluation courses at Batanghari University Jambi. The results showed that from a comparison on the standard deviation obtained a difference of 0.59 between student learning outcomes using and not using the Anates application. So, it can be concluded that the use of Anates software based application is very helpful for students in processing and analyzing data. Thus, the use of media and learning models can be done simultaneously in order to facilitate the process of transforming information to students.
\end{abstract}

Keywords: Media, Anates, Learning Evaluation.

\section{Introduction}

According to Law No. 20 of 2003, education is a conscious and planned effort to develop all the potential that students have through the learning process. Education aims to develop the potential of children to have a religious spiritual, self-control, personality, intelligence, noble character, and have the skills needed as members of society and citizens. Therefore, education is one of the leading facilities that needs to be managed and managed as well as possible in line with the development of time and the development of human life [1].

The essence of education is the learning process, which is an attempt by someone to get a new character change as a whole, as a result of the experience of interaction with their environment. The learning process is influenced by the system in which there are a number of components. These components include the curriculum, teaching staff, formulation of objectives, selection and preparation of materials, use of effective learning strategies, use of appropriate media, and implementation of correct evaluations.

Learning media is a tool or intermediary that is useful to facilitate the teaching and learning process in an effort to streamline communication between teacher and students. This greatly helps the teacher in teaching and makes it easy for students to accept and understand the lesson. The use of instructional media in the teaching and learning process can arouse new desires and interests for students, generate motivation to learn, and even bring psychological influence on 
students. Besides being able to increase student motivation, the use or use of media can also increase students' understanding of the lesson [2].

The learning process used by many educators today tends to achieve curriculum target material, more concerned with memorizing concepts rather than understanding. This can be seen from the learning activities in the classroom which are always dominated by teaching staff in the delivery of material, usually educators only use the lecture method, where students just sit, take notes, and listen to what they say and little opportunity for students to ask questions. Besides the absence of assistive devices or tools for introducing the material presented if needed, for example, except OHPs, projectors, blackboards, or images contained in modules or literature books owned by students which in the end the learning is passive.

The use of media in the world of education in general and in the learning process in particular at this time has become a necessity in supporting the improvement of the world of education itself. This is because, the principle of modernization is not only manifested in the form of books as the main tool of education, but in all records of human experience. In addition, the teacher is also a driver of student creativity so that teachers are required to demonstrate in showing this creativity. Where, creativity itself is characterized by the activity of creating something that did not exist before or there is a tendency to create [3].

Many ways can be done by educators in developing the process of channeling information to students through the use of methods and learning models, where it can all be adjusted both from the material to be delivered and the ability of each student. This also applies to the use of media in teaching and learning activities, returning to the educator only for how the use of the media can run according to what has been stated in the lesson plan (syllabus) and syllabus. Thus, it can be said that between the use of media and methods both provide convenience for teachers in carrying out their assignments in the classroom.

Nasution provides an overview of the use of media and methods can be carried out in the implementation of teaching and learning activities in the classroom, among others as follows:

Development of interactive computer-assisted media developed following the ASSURE procedural model, where the steps to be followed are descriptive consisting of 6 steps namely analysis of student characteristics, goal setting, media and material selection, use of materials, student participation to be active in learning, evaluation /revision. Meanwhile, the conceptual model of the development of computer-aided media follows the theory of behavior learning proposed by Gagne, that is, learning done by humans can be arranged and changed to develop certain forms of behavior in a person, or enhance abilities, or change their behavior, so that instructional media developed are based on "Programmed Instruction". In connection with the use of "Programmed Instruction" as a developed media concept, the learning theory that is in accordance with the character of "Programmed Instruction" is the association learning theory, stating that the relationship between stimulus and response. The relationship will be stronger if often repeated and the correct response is given praise or other ways that provide a sense of satisfaction and pleasure.

\section{Theoretical Framework}

\section{a. Instructional Media}

Learning media as a whole can be defined as aids in the form of physical or non-physical which is deliberately used as an intermediary between the teacher and students in understanding learning material to be more effective and efficient. So that learning material is more quickly accepted by students as a whole and attracts students' interest to study further. In short, the media is a tool used by teachers with a design that is adjusted to improve the quality of learning [4]. 
What is meant by educational media (tools) are tools used by educators in delivering educational or teaching material [5]. Meanwhile, Media is a tool that can be used as a distributor of messages to achieve teaching objectives [6]. Thus, it can be concluded that educational media is a tool or method or model used in the learning process so that teaching objectives can be achieved.

\section{b. Anates}

Anates is a computer software program that aims to analyze items. This program is particularly useful for teachers generally for observers of educational evaluation. Meanwhile, for prospective teachers such as (FKIP students) this software is very useful to be used as an exercise in how to analyze weighted items, which have different power, reliability and good deception. This program was developed by Drs. Karno To, M.Pd. a Psychology lecturer at UPI and Mr. Yudi Wibisono S.T.

Basically, its usefulness is the same as other data processing items, but the operation is easier. In addition, the results have been directly analyzed by the program so that there is no need to bother to analyze it again with the existing criteria. The functions and benefits of anates are certainly for analyzing data on multiple choice questions, which are tested. Anates application is very easy to use and very helpful in analyzing multiple choice questions (multiple choice). The use of the Anates application can be divided into several aspects or benchmarks namely content, ease, appearance, and feasibility.

\section{c. Leaning Evaluation}

Thus, it is expected that with the help of software-based applications that Anates can be an alternative for students to be able to process data, both with regard to analyzing the quality of the questions, answer choices, measures of success of answers, and so forth. That item analysis or item analysis is the study of test questions in order to obtain a set of questions that have adequate quality [7]. Analysis of the items there are two approaches, including the following:

a. Classical. Classical item analysis is the process of analyzing items through information from students' answers in order to improve the quality of the items concerned using classical test theory. The advantages of classic item analysis are that it is inexpensive, can be carried out daily quickly using a computer, is simple, familiar and can use data from several students or small samples.

b. Modern. Modern item analysis is a review of items using Item Response Theory (IRT) or item answer theory. This theory is a theory that uses mathematical functions to connect the opportunity of correct answers to a problem with the ability of students. Other names for IRT are Latent Trait Theory (LTT) or Characteristic Curve Theory (ICC).

\section{Research Methodology}

In qualitative research, the main consideration in data collection is the selection of informants. This is because, in a qualitative research is not used the term population. The technique used by researchers is purposive sample with certain considerations [8]. Where, the experimental class was treated using anates software based media while the control class was treated manually in the learning evaluation course. Sampling in this study uses purposive sampling technique. Purposive sampling is a sampling technique with certain considerations [8]. Purposive sampling is taken by considering the type of research used where this research 
requires a control class and an experimental class. Meanwhile, to obtain the results of research as expected, the procedures and stages that must be considered, namely:

a. Problem recognition stage: (a) Identifying the problem, (b) Analyzing the problem in depth by referring to relevant theories, (c) Identifying relevant actions.

b. Preparation stage: (a) Preparation of researcher schedules, (b) Preparation of learning plans, (c) Compilation of evaluation questions.

c. The stage of preparing the experimental plan. The stage of preparing this experimental plan, the actions taken are arranged in several stages, namely the stage of composing the experiment, testing the test questions (Pre-Test and Post-Test), analyzing the test questions about the test questions (Pre-Test and Post-Test).

d. The implementation phase of the experiment. At this stage of implementation, the researcher implements hypotheses of action, where these action hypotheses are used to test their correctness through planned actions.

e. Stages of observation. At this observation stage, researchers conducted observations on students who are conducting teaching and learning activities under the guidance of the teacher.

f. Stage of preparing the report. At the stage of compiling this report, the researcher compiles a report of all activities that have been carried out while the researcher is conducting research at the University of Batanghari Jambi.

\section{Result and Discussion}

\section{a. Result}

To analyze the results of data processing in the research carried out, it can be carried out with data analysis techniques with comparative analysis. During the learning process the researcher gave pre-test 2 times. Below are the first and second pre-test results presented at the beginning of the learning process and at the end of the learning process.

Table 1. Initial Pre-Test and Final Pre-Test

\begin{tabular}{|c|c|c|c|c|c|c|c|c|c|}
\hline \multirow{2}{*}{ Name } & \multicolumn{2}{|c|}{ Pre-Test 1} & \multicolumn{2}{|c|}{ Prest-Tes 2} & \multirow{2}{*}{ Name } & \multicolumn{2}{|c|}{ Pre-Test1 } & \multicolumn{2}{|c|}{ Prest-Tes 2} \\
\hline & Score & Point & Score & Point & & Score & Point & Score & Point \\
\hline $\begin{array}{l}\text { Fepi } \\
\text { Purwaningsih }\end{array}$ & 10 & 25 & 15 & 37,5 & Sri Laraswati & 10 & 25 & 17 & 42,5 \\
\hline Hodijah & 16 & 40 & 20 & 50 & $\begin{array}{l}\text { Mariyanis } \\
\text { Sahputri }\end{array}$ & 20 & 50 & 12 & 30 \\
\hline $\begin{array}{l}\text { Mutia Samrotul } \\
\text { F }\end{array}$ & 9 & 22,5 & 25 & 62,5 & Sondang Purba & 17 & 42,5 & 19 & 47,5 \\
\hline Fitri Lestari & 18 & 45 & 23 & 57,5 & Agustianingsih & 14 & 35 & 30 & 75 \\
\hline Nanda Pratiwi & 6 & 15 & 21 & 52,5 & Imelda Devita & 10 & 25 & 7 & 25 \\
\hline Oktaviani & 14 & 35 & 13 & 32,5 & $\begin{array}{c}\text { Nende } \\
\text { Rahmawati }\end{array}$ & 22 & 55 & 24 & 55 \\
\hline $\begin{array}{l}\text { Melfa } \\
\text { Simanjuntak }\end{array}$ & 15 & 37,5 & 29 & 72,5 & $\begin{array}{l}\text { Deasriza Indah } \\
\text { Sari }\end{array}$ & 16 & 40 & 31 & 27,5 \\
\hline Mildawati & 11 & 27,5 & 21 & 52,5 & Eva Anggraini & 6 & 15 & 11 & 27,5 \\
\hline Cici Nurasiyah & 18 & 45 & 10 & 25 & Boy Hardiansyah & 18 & 45,5 & 26 & 60 \\
\hline
\end{tabular}


Table 2. Pre-Test Value of Control Class and Experiment Class

\begin{tabular}{|c|c|c|c|c|c|c|c|}
\hline \multirow[t]{2}{*}{ No. } & \multirow[t]{2}{*}{ Interval } & \multicolumn{2}{|c|}{$\begin{array}{c}\text { Class } \\
\text { Pre-Test Awal } \\
\end{array}$} & \multirow[t]{2}{*}{ No. } & \multirow[t]{2}{*}{ Interval } & \multicolumn{2}{|c|}{$\begin{array}{c}\text { Class } \\
\text { Pre-Test Akhir }\end{array}$} \\
\hline & & $\mathrm{Fi}$ & $\%$ & & & $\mathrm{Fi}$ & $\%$ \\
\hline 1 & $6-9$ & 3 & 16,67 & 1 & $7-11$ & 3 & 16,67 \\
\hline 2 & $10-13$ & 4 & 22,22 & 2 & $12-16$ & 3 & 16,67 \\
\hline 3 & $14-17$ & 6 & 33,33 & 3 & $17-21$ & 5 & 27,78 \\
\hline 4 & $18-21$ & 4 & 22,22 & 4 & $22-26$ & 4 & 22,22 \\
\hline 5 & $22-25$ & 1 & 5,55 & 5 & $27-31$ & 3 & 16,67 \\
\hline Total & & 9 & 100 & & Total & 9 & 100 \\
\hline
\end{tabular}

Table 3. Post-Test Result Values

\begin{tabular}{|c|c|c|c|c|c|c|c|c|c|}
\hline \multirow[t]{2}{*}{ Name } & \multicolumn{2}{|c|}{$\begin{array}{c}\text { Not Use } \\
\text { Anates }\end{array}$} & \multicolumn{2}{|c|}{ Used Anates } & \multirow[t]{2}{*}{ Name } & \multicolumn{2}{|c|}{$\begin{array}{c}\text { Not Use } \\
\text { Anates }\end{array}$} & \multicolumn{2}{|c|}{ Used Anates } \\
\hline & Score & Point & Score & Point & & Score & Point & Score & Point \\
\hline $\begin{array}{l}\text { Fepi } \\
\text { Purwaningsih }\end{array}$ & 10 & 25 & 11 & 27,5 & Sri Laraswati & 9 & 22,5 & 25 & 62,5 \\
\hline Hodijah & 9 & 22,5 & 8 & 20 & $\begin{array}{l}\text { Mariyanis } \\
\text { Sahputri }\end{array}$ & 20 & 50 & 26 & 65 \\
\hline Mutia Samrotul F & 12 & 30 & 29 & 77,5 & Sondang Purba & 19 & 47,5 & 27 & 67,5 \\
\hline Fitri Lestari & 18 & 45 & 17 & 42,5 & Agustianingsih & 19 & 47,5 & 26 & 65 \\
\hline Nanda Pratiwi & 9 & 22,5 & 14 & 35 & Imelda Devita & 14 & 35 & 15 & 37,5 \\
\hline Oktaviani & 11 & 27,5 & 16 & 40 & $\begin{array}{l}\text { Nende } \\
\text { Rahmawati }\end{array}$ & 8 & 20 & 9 & 22,5 \\
\hline $\begin{array}{l}\text { Melfa } \\
\text { Simanjuntak }\end{array}$ & 7 & 17,5 & 29 & 77,5 & $\begin{array}{l}\text { Deasriza Indah } \\
\text { Sari }\end{array}$ & 9 & 22,5 & 27 & 67,5 \\
\hline Mildawati & 11 & 27,5 & 14 & 35 & Eva Anggraini & 11 & 27,5 & 28 & 70 \\
\hline Cici Nurasiyah & 9 & 22,5 & 17 & 42,5 & Boy Hardiansyah & 6 & 15 & 29 & 77,5 \\
\hline
\end{tabular}

Table 4. Control Class and Experiment Class Post-Test Values

\begin{tabular}{|c|c|c|c|c|c|c|c|}
\hline \multirow[t]{2}{*}{ No. } & \multirow[t]{2}{*}{ Interval } & \multicolumn{2}{|c|}{$\begin{array}{c}\text { Kelas } \\
\text { Not Use Anates }\end{array}$} & \multirow[t]{2}{*}{ No. } & \multirow[t]{2}{*}{ Interval } & \multicolumn{2}{|c|}{$\begin{array}{c}\text { Kelas } \\
\text { Use Anates }\end{array}$} \\
\hline & & Fi & $\%$ & & & $\mathbf{F i}$ & $\%$ \\
\hline 1 & $6-8$ & 3 & 16,67 & 1 & $8-12$ & 3 & 16,67 \\
\hline 2 & $9-11$ & 9 & 50,00 & 2 & $13-17$ & 6 & 33,33 \\
\hline 3 & $12-14$ & 2 & 11,11 & 3 & $18-22$ & 0 & 0 \\
\hline 4 & $15-17$ & - & 0 & 4 & $23-27$ & 5 & 27,78 \\
\hline 5 & $18-20$ & 4 & 22,22 & 5 & $28-32$ & 4 & 22,22 \\
\hline Total & & 9 & 100 & Total & & 9 & 100 \\
\hline
\end{tabular}

Analysis of the data obtained in the study by using the two average similarity test aimed at determining the successful application in the use of anates software-based applications in learning evaluation courses at Batanghari University, as follows:

Table 5. Mean Frequency Which Does Not Use Anates

\begin{tabular}{llllll}
\hline Interval & $\mathrm{F}$ & $\mathrm{X}$ & $\mathrm{FX}$ & $\mathrm{X} 2$ & $\mathrm{~F}(\mathrm{X} 2)$ \\
\hline $6-8$ & 3 & -2 & -6 & 4 & 12 \\
$9-11$ & 9 & -1 & -9 & 1 & 9 \\
$12-14$ & 2 & 0 & 0 & 0 & 0 \\
$15-17$ & - & 1 & 0 & 1 & 0 \\
$18-20$ & 4 & 2 & 8 & 4 & 16 \\
\hline Total & 18 & & -7 & 10 & 37 \\
\hline
\end{tabular}


Table 6. Mean Frequencies That Use Anates

\begin{tabular}{llllll}
\hline Interval & $\mathrm{F}$ & $\mathrm{X}$ & $\mathrm{FX}$ & $\mathrm{X} 2$ & $\mathrm{~F}(\mathrm{X} 2)$ \\
\hline $8-12$ & 3 & -2 & -6 & 4 & 12 \\
$13-17$ & 6 & -1 & -6 & 1 & 6 \\
$18-22$ & 0 & 0 & 0 & 0 & 0 \\
$23-27$ & 5 & 1 & 5 & 1 & 5 \\
$28-32$ & 4 & 2 & 1 & 4 & 16 \\
\hline Jumlah & 18 & & 10 & 39 \\
\hline
\end{tabular}

Standard deviation for not using the Anates application

$$
\begin{aligned}
& \mathrm{SD}=i \quad \sqrt{\frac{\mathrm{f}(\mathrm{x})}{\mathrm{N}}-\left(\frac{\sum \mathrm{fx}^{2}}{\mathrm{~N}}\right)} \\
& \mathrm{SD}=5 \sqrt{\frac{-7}{18}-\left(\frac{37}{18}\right)} \\
& \mathrm{SD}=7,82
\end{aligned}
$$

Standard deviations for using the Anates application

$$
\begin{aligned}
& \mathrm{SD}=i \sqrt{\frac{\sum \mathrm{f}(\mathrm{x})}{\mathrm{N}}-\left(\frac{\sum \mathrm{fx}^{2}}{\mathrm{~N}}\right)} \\
& \mathrm{SD}=5 \sqrt{\frac{1}{18}-\left(\frac{39}{18}\right)} \\
& \mathrm{SD}=7,23
\end{aligned}
$$

Meanwhile, to find the value of $\mathrm{t}$ :

$$
\begin{aligned}
& \mathrm{t}=\frac{X 1}{S X 1-S X 2} \\
& =\frac{18}{7,82-7,23} \\
& =30,51
\end{aligned}
$$

\section{Discussion}

Based on research data it is known that learning by using the Anates application makes students more enthusiastic even though at first it had difficulty in its use. In addition, after various actions through the initial and final pre-test, treatment, and post-test activities, finally the ability and ability to analyze the data in each student can be measured and analyzed using 
the new media to be used for them. Nevertheless, it is hoped that gradually the use of this media will further improve the quality of learning received by students.

Learning media as a whole can be defined as aids in the form of physical or non-physical which is deliberately used as an intermediary between the teacher and students in understanding learning material to be more effective and efficient. So that learning material is more quickly accepted by students as a whole and attracts students' interest to study further. In short, the media is a tool used by teachers with a design that is adjusted to improve the quality of learning [9].

Based on this explanation, the use of media is not only an intermediary to transfer information to students, but can improve lectures in a better and new direction to be applied in the future. This was also stated in the research of researcher where more learning models and media gave teachers more choices in choosing learning models and media which of course were adjusted to the expected learning goals. The use of learning models and media is very useful in the learning process when used appropriately [10].

\section{Conclusion}

a. Students still receive unsatisfactory results without using the Anates application. This indicates that students who do not use are still lacking confidence in the results of the analysis of their processed data.

b. Students who use the Anates application are fairly quick in analyzing data despite having difficulty in using it for the first time. This indicates that the use of the Anates application is very helpful for students in understanding the material in the learning evaluation course.

c. Judging from the comparison on the standard deviation obtained a difference of 0.59 between student learning outcomes that use by not using the Anates application. So, it can be concluded that the use of Anates software based application is very helpful for students in processing and analyzing data. Thus, the use of media and learning models can be done simultaneously in order to facilitate the process of transforming information to students.

\section{References}

[1] Depdiknas. 2003. Undang-Undang RI Nomor 20 Tahun 2003, tentang Sistem Pendidikan Nasional.

[2] Hamdani. 2011. Strategi Belajar Mengajar. Bandung: Pustaka Setia.

[3] Mulyasa. 2007. Menjadi Guru Profesional: Menciptakan Pembelajaran Kreatif dan Menyenangkan. Bandung: Remaja Rosdakarya.

[4] Musfiqon, HM. 2012. Pengembangan Media dan Sumber Pembelajaran. Jakarta: PT. Prestasi Pustakaraya.

[5] Notoatmodjo, S. 2009. Pengembangan Sumber Daya Manusia. Jakarta: PT. Rineka Cipta

[6] Djamarah, S.B and Aswan Zain. 2006. Strategi Belajar Mengajar. Jakarta: PT. Rineka Cipta.

[7] Wahidmurni, Alfin Mustikawan dan Ali Ridho. 2010. Evaluasi Pembelajaran (Kompetensi dan Praktik). Malang: Nuha Litera

[8] Sugiyono. 2015. Metode Penelitian Pendidikan (Pendekatan Kuantitalif, Kualitatif, dan $R \& D)$. Bandung: CV. Alfabeta. 
[9] Musfiqon, HM. 2012. Pengembangan Media dan Sumber Pembelajaran. Jakarta: PT. Prestasi Pustakaraya.

[10] Ramadhany, T, Dewi K, and Deskoni. 2015. Analisis Model dan Media Pembelajaran yang Digunakan oleh Guru Pada Mata Pelajaran Ekonomi Di SMA Se-Kecamatan Inderalaya. Jurnal Profit, Vol. 2, No. 1, Mei 2015. Hal: 34-45. 